\title{
論文
}

\section{International Comparison of the Viscosity of the \\ ASTM Standard Oil Samples}

by

\author{
Yasumitsu Kurano, Kiyoshi Yoshida, Kimio Kurase, and Michio Kawata
}

(National Research Laboratory of Metrology, Tokyo 173)

The kinematic viscosity measurements of the ASTM (American Society for Testing and Materials) standard oil samples have been carried out as the ASTM cooperative kinematic viscosity testing program under the supervision of the ASTM since 1959. Our laboratory has taken part in this testing program every year since 1969.

This paper describes the results of kinematic viscosity measurements obtained on the standard oil samples with normal flow U-tube master viscometers at our Laboratory and the results of comparison among the data obtained with each capillary-type master viscometer at foreign national laboratories and our laboratory over the period from 1969 to 1978.

It is concluded that the difference between the viscosity measurements obtained at our laboratory and the foreign national laboratories is within $\pm 0.2 \%$ in the range of viscosity less than $2.4 \times 10^{3} \mathrm{~mm}^{2} / \mathrm{s}(\mathrm{cSt})$ and $+0.00 \sim+0.42 \%$ in the range less than $8.1 \times 10^{4}$ $\mathrm{mm}^{2} / \mathrm{s}(\mathrm{cSt})$ over the temperature range from 20 to $40^{\circ} \mathrm{C}$.

\section{ASTM 粘度標準液の粘度の国際比較}

\author{
倉野 恭充・吉田＼cjkstart清・倉瀬 公男・川田 裕郎*
}

(原稿受理 : 1979年 1 月17日)

\section{1.はじめに}

粘度の国際比較が米国の ASTM*1 で計画され，1959年以来 ASTM Cooperative Viscosity Testing Program として毎年実施 されている，この比較測定の試料としては，ASTM粘度標準液*2

* 計量研究所 東京都板橋区加賀 $1-10-4$

*1 American Society for Testing and Materials の略, 米国材料 試験協会.

*2 米国では, 古くから APJ (American Petroleum Institute) の 粘度標準液が一般に供給されていたが，1959年 1 月から ASTM 粘度標準液がこれに代わった。一方, NBS(National Bureau of Standards) でも NBS 標準液が 1938年から供給されていたが, 1967年にこれを廃止し，ASTM 粘度標準液に統合した。ASTM 粘度標準液の種類は統合前 7 種類であったが, 現在 9 種類となっ ている.
（以下，標準液とする）が用いられ，それらの標準液が各国の主 な試験研究所に送られて粘度の比較実験が行われている.わが国 の計量研究所にも参加の要請があり, 1969年以来参加してきた. 本報告では，1969〜1978年度の10年間にわたって筆者らが行っ てきた計量研究所の測定，および ASTM で取りまとめられた参 加研究所の測定結果の資料1を基に, 粘度の国際比較の概要, 参 加研究所間の測定結果の比較について述べる.

\section{2. 粘度の国際比較の概要}

\section{$2 \cdot 1$ 参加研究所と使用粘度計}

Table I に1969〜1978年度までの参加研究所，およびそれぞれ の参加研究所に扣ける使用粘度計の種類を示す.

Table 1 に*印で示したように, 国立の計量標準研究所として 
Table I Participating laboratories in the annual ASTM cooperative viscosity testing program and the viscometers used at each laboratory.

\begin{tabular}{|c|c|c|c|c|c|c|c|c|c|c|c|c|}
\hline \multirow{2}{*}{$\begin{array}{l}\text { Lab. } \\
\text { Code } \\
\text { No. }\end{array}$} & \multirow{2}{*}{ Laboratory } & \multirow{2}{*}{ Type of viscometer } & \multicolumn{10}{|c|}{$\begin{array}{l}O: \text { Participation } \\
-: \text { Nonparticipation }\end{array}$} \\
\hline & & & '69 & '70 & '71 & & ear & '74 & '75 & '76 & '77 & '78 \\
\hline 1 & $\begin{array}{l}\text { Gulf Research and Development Company } \\
\text { (USA) }\end{array}$ & $\left.\begin{array}{l}\text { Cannon-Ubbelohde, } \\
\text { Cannon-Fenske Routine }\end{array}\right\}$ & $\bigcirc$ & & O & O & $\bigcirc$ & $\bigcirc$ & $\bigcirc$ & $\bigcirc$ & O & O \\
\hline 2 & $\begin{array}{l}\text { Exxon Research and Engineering Company } \\
\text { (USA) }\end{array}$ & Ubbelohde & $\bigcirc$ & 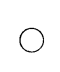 & O & O & O & O & $\bigcirc$ & - & - & $\bigcirc$ \\
\hline 3 & Atlantic Richfield Company (USA) & $\left.\begin{array}{l}\text { Cannon Master, } \\
\text { Cannon-Ubbelohde }\end{array}\right\}$ & O & 0 & $\bigcirc$ & - & - & - & - & - & - & - \\
\hline 4 & Rohm and Haas Company (USA) & Cannon Master & $\bigcirc$ & & O & $\bigcirc$ & O & $\bigcirc$ & $\bigcirc$ & O & $\mathrm{O}$ & O \\
\hline 5 & $\begin{array}{l}\text { Standard Oil Company of California } \\
\text { (USA) }\end{array}$ & $\left.\begin{array}{l}\text { Zeitfuchs Transparent, } \\
\text { Zeitfuchs Cross-Arm }\end{array}\right\}$ & O & & O & O & O & $\bigcirc$ & $\bigcirc$ & $\bigcirc$ & 0 & $\bigcirc$ \\
\hline 6 & United States Testing Company (USA) & $\left.\begin{array}{l}\text { Cannon-Ubbelohde, } \\
\text { Ubbelohde }\end{array}\right\}$ & 0 & O & O & ○ & ○ & ○ & $\bigcirc$ & O & O & - \\
\hline * 7 & National Bureau of Standards (USA) & Cannon Master & 0 & 0 & O & 0 & 0 & O & O & $\bigcirc$ & O & $\bigcirc$ \\
\hline 8 & $\begin{array}{l}\text { Koninklijke/Shell-Laboratorium, } \\
\text { Amsterdam (Holland) }\end{array}$ & $\left.\begin{array}{l}\text { Cannon-Fenske Routine, } \\
\text { Ostwald-Gruneisen }\end{array}\right\}$ & O & & O & $\bigcirc$ & 0 & 0 & $\bigcirc$ & 0 & O & $\bigcirc$ \\
\hline 9 & Texaco Research Center (USA) & $\left.\begin{array}{l}\text { Cannon-Fenske Routine, } \\
\text { Cannon-Ubbelohde }\end{array}\right\}$ & $\bigcirc$ & $\bigcirc$ & O & O & - & - & - & - & - & - \\
\hline * 10 & National Research Council (Canada) & Cannon Master & $\bigcirc$ & $\bigcirc$ & O & O & $\bigcirc$ & O & O & 0 & O & O \\
\hline 11 & Sun Oil Company (USA) & - & $\bigcirc$ & $\bigcirc$ & $\bigcirc$ & $\bigcirc$ & - & $\bigcirc$ & $\bigcirc$ & O & - & O \\
\hline 12 & Amoco Oil Company (USA) & Fitzsimons & - & O & $\bigcirc$ & $\bigcirc$ & $\bigcirc$ & O & $\bigcirc$ & $\bigcirc$ & O & $\bigcirc$ \\
\hline 13 & Department of National Defence (Canada) & Cannon-Fenske Routine & O & 0 & $\bigcirc$ & $\bigcirc$ & - & $\bigcirc$ & $\bigcirc$ & $\bigcirc$ & $\bigcirc$ & $\bigcirc$ \\
\hline 14 & Continental Oil Company (USA) & Zeitfuchs Long-Capillary & - & 0 & - & 一 & - & - & $\bigcirc$ & - & - & - \\
\hline 15 & $\begin{array}{l}\text { Mobil Reserch and Development Corp. } \\
\text { (USA) }\end{array}$ & Cannon-Fenske Routine & O & 0 & $\bigcirc$ & O & $\bigcirc$ & 0 & 0 & $\bigcirc$ & $\mathrm{O}$ & 0 \\
\hline 16 & $\begin{array}{l}\text { British Petroleum Research Centre } \\
\text { (England) }\end{array}$ & IP Suspended Level & O & & ○ & ○ & O & O & O & 0 & & 0 \\
\hline * 17 & National Physical Laboratory (England) & $\left.\begin{array}{l}\text { U-Tube Type BS/V/MV, } \\
\text { Suspended Level } \\
\text { BS/IP/SL/MV }\end{array}\right\}$ & 0 & & O & ○ & $\bigcirc$ & O & O & O & & O \\
\hline * 18 & $\begin{array}{l}\text { National Research Laboratory of } \\
\text { Metrology (Japan) }\end{array}$ & Normal flow U-Tube Master & $\bigcirc$ & $\bigcirc$ & O & ○ & O & $\bigcirc$ & $\bigcirc$ & $\bigcirc$ & O & $\bigcirc$ \\
\hline 19 & AF Aero Propulsion Laboratory (USA) & Cannon-Fenske Routine & $\bigcirc$ & $\bigcirc$ & O & 0 & 0 & $\bigcirc$ & $\bigcirc$ & $\bigcirc$ & & $\mathrm{O}$ \\
\hline 20 & $\begin{array}{l}\text { Materials Research Laboratories } \\
\text { (Australia) }\end{array}$ & Ubbelohde Master & 0 & 0 & 0 & - & 0 & $\bigcirc$ & O & $\bigcirc$ & $\bigcirc$ & $\bigcirc$ \\
\hline * 21 & $\begin{array}{l}\text { Physikalish-Technische Bundesanstalt } \\
\text { (Germany) }\end{array}$ & Ubbelohde & - & - & $\bigcirc$ & $\bigcirc$ & $\bigcirc$ & $\bigcirc$ & 0 & $\bigcirc$ & & 0 \\
\hline 22 & $\begin{array}{l}\text { Institute for Physical Chemistry TNO } \\
\text { (Holland) }\end{array}$ & Special Ostwald & - & - & $\bigcirc$ & 0 & 0 & $\bigcirc$ & 0 & $\bigcirc$ & & 0 \\
\hline * 23 & $\begin{array}{l}\text { Office National Des Mesures } \\
\text { (Hungary) }\end{array}$ & Ubbelohde Master & - & - & - & $\bigcirc$ & $\bigcirc$ & $\bigcirc$ & 0 & $\bigcirc$ & & 0 \\
\hline * 24 & $\begin{array}{l}\text { National Measurement Laboratory } \\
\text { (Australia) }\end{array}$ & NML Double-Bulbed U-Tube & - & - & O & $\bigcirc$ & - & $\bigcirc$ & $\bigcirc$ & 0 & 0 & - \\
\hline * 25 & $\begin{array}{l}\text { Swiss Federal Laboratory for Testing } \\
\text { Materials and Research (Switzerland) }\end{array}$ & Standerd Ubbelohde & - & - & $\bigcirc$ & O & $\bigcirc$ & $\bigcirc$ & - & $\bigcirc$ & 0 & 0 \\
\hline * 26 & Institute for Metrology (Romania) & Cannon Master & - & - & - & - & O & O & - & 0 & & \\
\hline * 27 & $\begin{array}{l}\text { Czechoslovak Institute of Metrology } \\
\text { (Czechoslovakia) }\end{array}$ & Ubbelohde & - & - & - & - & 0 & - & - & $\bigcirc$ & & \\
\hline 28 & Sohio Research (USA) & Zeitfuchs & - & - & - & - & - & 0 & - & 0 & & \\
\hline 29 & $\begin{array}{l}\text { U.S. Army Metrology and Calibration } \\
\text { Center (USA) }\end{array}$ & Cannon Master & - & - & - & - & - & - & - & - & & \\
\hline $\mathrm{CIC}$ & Cannon Instrument Company (USA) & $\left.\begin{array}{l}\text { Cannon Master, } \\
\text { Cannon-Ubbelohde Master, } \\
\text { Cannon-Ubbelohde }\end{array}\right\}$ & 19 & 21 & 24 & 23 & 22 & 25 & 23 & 25 & 24 & 23 \\
\hline
\end{tabular}

* : National standard laboratory 
はわが国の計量研究所のほか，NBS(National Bureau of Standards, 米国), NRC (National Research Council, カナダ), NPL (National Physical Laboratory, 英国), PTB (Physikalish-Technische Bundesanstalt, 西ドイッ), ONM (Office National Des Mesures,ハンガリー), NML(National Measurement Laboratory, オーストラリア)， SFLTMR (Swiss Federal Laboratory for Testing Materials and Research, スイス), IM (Institute for Metrology, ルーマニア), CIM (Czechoslovak Institute of Metrology，チェコスロバキア）の10研密所で，他は公立扣よび石油 関係等の民間研究所である。

ASTM Cooperative Viscosity Testing Program の目的は, 当

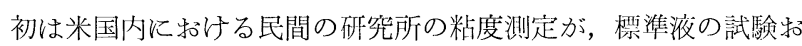
よび供給業務を担当している米国の CIC (Cannon Instrument Company) とどの 程度一致しているかを調べることにあったよ らであるが，次第に 各国の研宽所への参加の呼び掛けとなり， Table I 亿示すように年を损って国際色豊かなプログラムへと発 展してきている.

1979年度の参加研究所は米国，カナダ，英国，オランダ，スイ ス, ハンガリー, 西ドイッ, オーストラリア拈よび日本の 9 力国, 23研究所 (CIC を含む) であった.

\section{$2 \cdot 2$ 測定試料}

湘定試料は，現在米国内で一般に供給されている栖準液 S-3 から S-30000の 9 種類で, 動粘度範团は約 1 $81,000 \mathrm{~mm}^{2} / \mathrm{s}$ (約 $1 \sim 81,000 \mathrm{cSt})$, 測定温度範囲は $-53.89 \sim 100^{\circ} \mathrm{C}\left(-65 \sim 212^{\circ} \mathrm{F}\right)$ て ある. CIC は, 参加研密所に刘してこれらの標準液の5ち $2 \sim 3$ 種類を測定温度を指定して割り当てる。 また，この国際比較の幹 事役である CIC は，全参加研究所に割り当てた標準液と同一口 ットの標準液の動粘度を指定した全温度で測定し，動粘度の相互 比較の際の基準值としている。したがって, 参加各研究所は全種 類の標準液の動粘度測定に参玑しなくても，CICから送られてく る資料1（每年，ASTM に提出するため，CICでまとめられた参 加各研究所の測定結果叔よびその比較等の報告書の写し) を基 に, CIC の動粘度測定值からの偏差によって参加研究所間の比較 を行うことができる。

Table II 標準液の種類扣よび指定測定温度に扣ける概略の動 粘度值を示す。これらの標準液は，S-3から S-600のものは鉣油 であり，S-2000から S-30000のものはポリブテン（ノルマルプ テンとイソブテンの共重合体) である.

\section{$2 \cdot 3$ 動粘度の測定方法}

動粘度の測定については，CICから次のような方法によること が指示されている。すなわち, 割り当てられた 1 種類の標準液に ついて 1 指定測定温度で 2 本の細管粘度計を用い, それぞれの粘 度計で標準液の流下時間を 3 回ずつ繰り返し測定し, 更に日を改 めて同様な測定を反復することが取り決められている. 動粘度は, 得られた 6 つの流下時間の平均值にそれぞれの粘度計の粘度計定 数を乗じて算出する。以上の方法に従って各標準液ごとに CIC から送られてくるデータシートに測定結果を記入するほか, 粘度 計の型式, 番号, 平均有效液柱高さ, 動粘度計算式, 測時, 測温 法等も併せて記入して報告する．CICでは 2 本の粘度計により得 られた動粘度の平均を取って参加研究所の動粘度測定值としてい る.

測定に使用する細管粘度計は，できればマスター粘度計を用い ることが CIC から要請されている。 マスタ一粘度計は, $20^{\circ} \mathrm{C} の$ 蒸留水の粘度を基準にして粘度計定数が高精度に決定されている 粘度計で，通常使用されている細管粘度計に比べて細管部を長く し (40〜 50cm), 種々の誤差を小さくして粘度の精密な測定に有利 な構造に設計されている。しかし, 粘度計の型式执よび粘度計定 数の決定法については特に指定されていないので, Table I に示 すように種々の型式のガラス製細管粘度計が使用されている.

なお，測定温度については，1969年度までは1948年国際実用温 度目盛（IPTS-48）によることが，1970年度以降は改訂された IPTS-682) とよることが要請された.

\section{3. 計量研究所の測定および測定結果}

\section{$3 \cdot 1$ 動粘度測定}

動粘度の 測定には, 正流形細管式比較標準粘度計 ${ }^{3)}$ (Normal flow U-tube master viscometer, 以下，標準粘度計とする）を用 いた．Fig. 1 飞標準粘度計の棈造を示したが，U字管の一方は 測時球と細管からなり，他方の管の下部は試料だめ容器となって いる. 測時球の体積は $3 \sim 21 \mathrm{~cm}^{3}$ 程度, 細管は内径が $0.4 \sim 9 \mathrm{~mm}$ 程度で, 長さが $45 \mathrm{~cm}$, 試料だめ容器の内径は $30 \sim 60 \mathrm{~mm}$ 程度の 寸法を持っている.

測定原理は, 一定体積の試料を粘度計内に採取し, 液柱差を与 えて測時球上下の $\mathrm{m} 1, \mathrm{~m} 2$ の二標線間を試料が細管を通って自然 流下するのに要する時間を測定して動粘度を求める。すなわち,

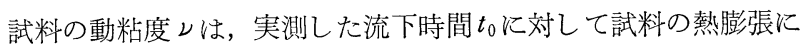

Table II Approximate kinematic viscosity of the ASTM viscosity standard oil samples.

\begin{tabular}{|c|c|c|c|c|c|c|c|c|c|}
\hline \multirow{2}{*}{$\begin{array}{c}\text { Viscosity } \\
\text { standard } \\
\text { designation }\end{array}$} & \multicolumn{9}{|c|}{ Approximate kinematic viscosity $\left(\mathrm{mm}^{2} / \mathrm{s}\{\mathrm{cSt}\}\right)$} \\
\hline & $\begin{array}{l}-53.89^{\circ} \mathrm{C} \\
\left(-65^{\circ} \mathrm{F}\right)\end{array}$ & $\begin{array}{c}-40^{\circ} \mathrm{C} \\
\left(-40^{\circ} \mathrm{F}\right)\end{array}$ & $\begin{array}{c}20^{\circ} \mathrm{C} \\
\left(68^{\circ} \mathrm{F}\right)\end{array}$ & $\begin{array}{c}25^{\circ} \mathrm{C} \\
\left(77^{\circ} \mathrm{F}\right)\end{array}$ & $\begin{array}{l}37.78^{\circ} \mathrm{C} \\
\left(100^{\circ} \mathrm{F}\right)\end{array}$ & $\begin{array}{c}40^{\circ} \mathrm{C} \\
\left(104^{\circ} \mathrm{F}\right)\end{array}$ & $\begin{array}{l}50^{\circ} \mathrm{C} \\
\left(122^{\circ} \mathrm{F}\right)\end{array}$ & $\begin{array}{l}98.89^{\circ} \mathrm{C} \\
\left(210^{\circ} \mathrm{F}\right)\end{array}$ & $\begin{array}{l}100^{\circ} \mathrm{C} \\
\left(212^{\circ} \mathrm{F}\right)\end{array}$ \\
\hline $\mathrm{S}-3$ & 300 & 80 & 4.6 & 4.0 & 3.0 & 2.9 & - & 1.2 & 1.2 \\
\hline$S-6$ & - & - & 11 & 8.9 & 6.0 & 5.7 & - & 1.8 & 1.8 \\
\hline $\mathrm{S}-20$ & - & - & 44 & 34 & 20 & 18 & - & 4.0 & 3.9 \\
\hline$S-60$ & - & - & 170 & 120 & 60 & 54 & - & 7.4 & 7.2 \\
\hline$S-200$ & - & - & 640 & 450 & 200 & 180 & - & 17 & 17 \\
\hline$S-600$ & - & - & 2400 & 1600 & 600 & 520 & 280 & 33 & 32 \\
\hline$S-2000$ & - & - & 8700 & 5600 & 2000 & 1700 & - & 78 & 75 \\
\hline $\mathrm{S}-8000$ & - & - & 37000 & 23000 & 8000 & 6700 & - & - & - \\
\hline$S-30000$ & - & - & - & 81000 & 27000 & 23000 & 11000 & - & - \\
\hline
\end{tabular}




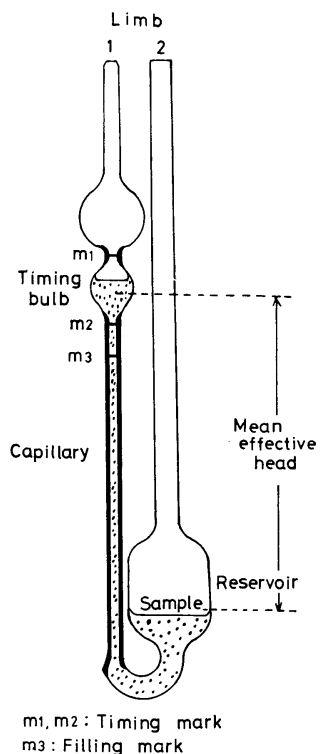

Fig. 1 Normal flow U-tube master viscometer.

関する補正 $\varepsilon_{1}(-0.11 \sim+0 \%)$, 空気の密度に関する補正 $\varepsilon_{2}( \pm$ $0.01 \%$ 以内) 扤よび指定測定温度と実際の測定温度との差による 動粘度変化分に関する補正 $\varepsilon_{3}( \pm 0.06 \%$ 以内）を考虑したものに， 標準粘度計の粘度計定数 $C$ を乗じた次式により計算する

$$
\nu=C t_{0}\left(1+\varepsilon_{1}+\varepsilon_{2}+\varepsilon_{3}\right)
$$

計量研究所では, 約 $0.5 \sim 200,000 \mathrm{~mm}^{2} / \mathrm{s}\{\mathrm{cSt}\}$ の広範囲の液体 粘度の精密比較測定が可能な標準粘度計群（1 組10本からなる標 準粘度計群が 2 組）を所有して打り，それらの粘度計定数は 20 ${ }^{\circ} \mathrm{C}$, 大気圧下の蒸留水の動粘度 $1.0038 \mathrm{~mm}^{2} / \mathrm{s}\{\mathrm{cSt}\}$ を基準とした Stepping-up 法5)により決定されている。標準粘度計による粘度 の測定精度については既に検討が加えられて拉り，その值は絶対 測定との比較に怙いて $\pm 0.1 \%$ 以内であることが確かめられてい る3).

Table III Instrumental constants of the normal flow U-tube master viscometers.

\begin{tabular}{l|c|c}
\hline \multirow{2}{*}{$\begin{array}{c}\text { Viscometer } \\
\text { No. }\end{array}$} & \multicolumn{2}{|c}{ Instrumental constant } \\
\cline { 2 - 3 } & $C_{68}\left(\mathrm{~mm}^{2} / \mathrm{s}^{2}\{\mathrm{cSt} / \mathrm{s}\}\right)$ & $C_{74}\left(\mathrm{~mm}^{2} / \mathrm{s}^{2}\{\mathrm{cSt} / \mathrm{s}\}\right)$ \\
\hline $2-1$ & 0.0040154 & 0.0040169 \\
$2-31$ & 0.0065965 & 0.0065946 \\
$3-1$ & 0.021850 & 0.021866 \\
$3-31$ & 0.037404 & 0.037381 \\
$4-1$ & 0.19683 & 0.19707 \\
$4-31$ & 0.25100 & 0.25095 \\
$5-1$ & 2.1347 & 2.1349 \\
$5-31$ & 0.96277 & 0.9642 \\
$6-1$ & 6.7657 & 6.7642 \\
$6-31$ & 4.1192 & 4.1207 \\
$7-1$ & 15.552 & 15.553 \\
$7-31$ & 15.320 & 15.333 \\
$9-1$ & 79.100 & 79.097 \\
$9-31$ & 91.350 & 91.438 \\
\hline
\end{tabular}

Note : $C_{68}$ and $C^{\prime}{ }_{74}$ were calibrated in 1968 and 1974 , respectively.
Table III は，測定に使用した標準粘度計の粘度計定数を示し たものであるが，C' ${ }_{68}$ 抒よびC ${ }_{74}$ はそれぞれ1968年と1974年に決 定した粘度計定数であり ${ }^{4)}$, 両者の間には注とんど差はない。筆 者らは1973年度までは $\mathrm{C}_{68}$ を，1974年度以降は $\mathrm{C}_{74}$ を用いて粘 度を求めた。

標準粘度計用精密恒温水槽は, 光電式水銀温度調節器による比 例制御方式によって, 測定温度 $20 \sim 50^{\circ} \mathrm{C}$ の範囲において 0.001 $\sim \pm 0.003^{\circ} \mathrm{C}$ 以内の温度分布で，長時間にわたり恒温に保持でき るものを用いた。恒温水槽の温度測定には, 計量研究所温度標準 研究室で校正された 精度 $\pm 0.001^{\circ} \mathrm{C} の$ 白金抵抗温度計 ( 4 導線型) を用いた。 また，流下時間は $\pm 1 \times 10^{-6}$ の周波数精度を有する電 子式カウンターにより， $\pm 1 \times 10^{-4}$ の精度で測定した. Table IV は1969〜1978年度に特いて割り当てられた標準液について, 計量 研究所で測定した $6 つ の$ 流下時間の測定值の変動係数を, 使用し た標準粘度計ごとに示したものであるが，これを見るとその值は $\pm 0.01 〜 \pm 0.07 \%$ の範囲内にあり, 高精度の測定が行われたこと がわかる.な技，標準粘度計の流下時間は記載を省略したが，そ の值は約 $400 〜 2,800 \mathrm{~s}$ の範囲内であった。

Table IV Variation in the flow times of the master viscometers used in the measurements at the NRLM during the period from 1969 to 1978 .

\begin{tabular}{l|c}
\hline $\begin{array}{c}\text { Viscometer } \\
\text { No. }\end{array}$ & Variation in the flow times $(\%)$ \\
\hline $2-1$ & $0.021 \sim 0.046$ \\
$2-31$ & $0.015 \sim 0.040$ \\
$3-1$ & $0.012 \sim 0.044$ \\
$3-31$ & $0.013 \sim 0.022$ \\
$4-1$ & $0.012 \sim 0.053$ \\
$4-31$ & $0.022 \sim 0.072$ \\
$5-1$ & $0.008 \sim 0.042$ \\
$5-31$ & $0.016 \sim 0.032$ \\
$6-1$ & $0.008 \sim 0.044$ \\
$6-31$ & $0.009 \sim 0.035$ \\
$7-1$ & $0.015 \sim 0.053$ \\
$7-31$ & $0.007 \sim 0.049$ \\
$9-1$ & $0.032 \sim 0.033$ \\
$9-31$ & $0.015 \sim 0.021$ \\
\hline
\end{tabular}

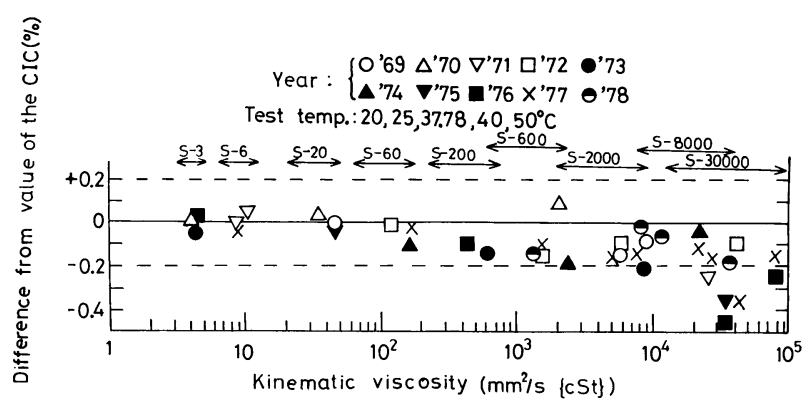

Fig. 2 Comparison of the results of viscosity measurements performed at the CIC and the NRLM. The minus sign indicates that the value of the NRLM is lower than that of the CIC. The CIC (Cannon Instrument Company) is the secretary in this testing program. 
Table V Comparison of the viscosities obtained with falling sphere-type absolute viscometer and capillary master viscometers for oil samples S-8000 at $20^{\circ} \mathrm{C}$.

\begin{tabular}{|c|c|c|c|}
\hline \multicolumn{2}{|c|}{ Viscometer } & $\begin{array}{c}\text { Viscosity } \\
(\mathrm{mPa} \cdot \mathrm{s}\{\mathrm{cP}\})\end{array}$ & Note \\
\hline $\begin{array}{l}\text { Capillary } \\
\text { master } \\
\text { viscometer }\end{array}$ & $\begin{array}{l}\text { Normal flow U-tube } \\
\text { type No. } 7-1 \\
\text { Normal flow U-tube } \\
\text { type No. } 7-31\end{array}$ & $\begin{array}{r}35412 \\
\\
35390 \\
\text { mean } 35401\end{array}$ & $\begin{aligned} \Delta & =\frac{35401-35437}{35437} \\
& \times 100=-0.10(\%)\end{aligned}$ \\
\hline $\begin{array}{l}\text { Falling } \\
\text { sphere- } \\
\text { type } \\
\text { absolute } \\
\text { viscometer }\end{array}$ & $\begin{array}{l}1.9814 \mathrm{~mm} \text { steel ball } \\
1.9816 \mathrm{~mm} \text { steel ball } \\
2.3786 \mathrm{~mm} \text { steel ball } \\
2.3786 \mathrm{~mm} \text { steel ball }\end{array}$ & $\begin{array}{r}35331 \\
35421 \\
35447 \\
35448 \\
\\
\text { mean } \\
35437\end{array}$ & $\begin{array}{l}\text { Diameter of glass cylinder: } \\
\qquad D=43.50(\mathrm{~mm}) \\
\text { Distance of fall: } \\
\quad l=99.96(\mathrm{~mm}) \\
\text { Density of the } \mathrm{S} 8000 / 78101 \text { at } 20^{\circ} \mathrm{C} \text { : } \\
\qquad \rho=0.88773\left(\mathrm{~g} / \mathrm{cm}^{3}\right)\end{array}$ \\
\hline
\end{tabular}

\section{$3 \cdot 2$ 計量研究所と CIC の動粘度測定值の比較}

Fig. 2 は, 1969 1978年度の計量研究所の測定結果と, CICの 測定結果を比較して縦軸に CIC の測定値からの偏差をとり，横 軸に標準液の動粘度をとって測定年度别にプロットして示した。 Fig. 2 から, 計量研究所と CIC の動粘度測定值の間には, 测定 動粘度範囲に和いてー0.46〜+0.09\%の偏差のあることがわかる. 更に詳細に見ると， S - 3 から S -600 の低粘度領域では計量研究 所の 17 の測定值すべてが，CICからの偏差で $\pm 0.20 \%$ 未満に入っ て招り, 非常に良く一致している. S-2000から S-30000 の高粘 度領域では, 21 の測定値の $72 \%$ CIC からの偏差で土0.20\%未 満に入って扣り，比較的良い一致を示している。一方，それぞれ の標準液について計量研究所と CIC との偏差を見ると， S-8000 を除けげ測定年度によらずいずれも一定の差を示している。これ は両者に抢いて，再現性の良い動粘度測定が行われていることを 示すものと言える.

S-8000 の1975〜 1977 年度の $20^{\circ} \mathrm{C}$ に扔ける動粘度測定值は CIC より低めで，その偏差はー0.35〜ー0.46\%と大きくなっている. この原因を調べる一つの方法として，1978年度の計量研究所に括 ける測定では, 標準粘度計で S -8000 の粘度を測定すると同時に 落球粘度計を用いて粘度の絶対測定を行い，両者の測定値を比較 してみた．落球粘度計にょる粘度の絶対測定の方法については, 筆者らが粘度標準の確立に関する研究に执いて検討した方法によ $つ た^{3)}$.

Table Vに落球粘度計扣よび標準粘度計による粘度の測定結果 を示したが, 両者の差は $0.10 \%$ 以内であった。 この結果は, 高粘 度用の標準粘度計によって得た S -8000 の $20^{\circ} \mathrm{C}$ の動粘度測定值に は0.10\%以上の系統誤差が入っていないことを示するのと考光ら れる。

\section{4. 参加研究所の動粘度測定值間の比較}

\section{4 ・1 1978年度参加22研究所と CIC の測定結果の比較}

Fig. 3 は，1978年度の測定に参加した 22 研究所の測定結界と CIC の測定結棵を比較したものであるが，CIC からの偏差で士 $0.20 \%$ 未満の測定值は参加研究所の全測定値の $76 \%$ であった。 ま た, CIC からの偏差を $\pm 0.30 \%$ 未満で整理すると, 全測定值の 82 \%がこの範囲内に入っていることがわかった．この数値は測定年

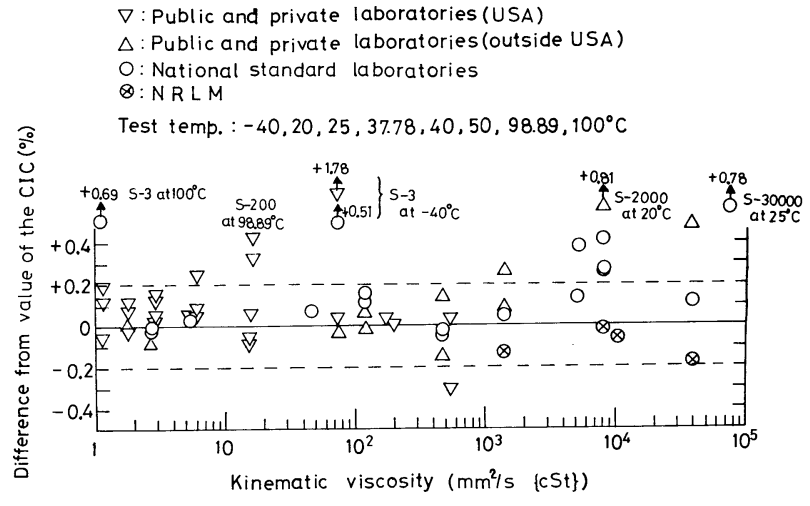

Fig. 3 Comparison of the results of the viscosity measurements performed at 22 laboratories (9 countries) with those at CIC in 1978.

度により多少の増減はあるが，ほぼ類似して招り大きな変化はな い。しかし，研究所によってはかなり大きな偏差を示していると ころがあった．大きな偏差を示した研究所のほとんどは Fig. 3 からわかるように, 低粘度標準液の低温度执よび高温度に拄ける 測定を受け持った研究所か, 高度粘標準液の測定を受け持った研 究所である。このことは, 低温度抢よび高温度, 高粘度に拈ける 動粘度測定が室温および低粘度に打ける測定に比べて, 例えば低, 高温槽の高精度恒温維持, 高粘度用粘度計の粘度計定数の高精度 決定等の困難が存在することが原因していると考えられる，

計量研究所の測定結果は CIC の值より低めであるが, 全部の 測定值が $\pm 0.20 \%$ 未満の偏差に入って扣り良く一致している。乙 かし, 高粘度領域で他の国立計量標準研究所との差がやや大きい.

\section{4 ・ 2 NBS, NPL, PTB と CIC の測定結果との比較}

Fig. 4 は, NBS, NPL, PTB 等の著名な国立計量標準研究所 の測定結果と，CIC の測定結果を 1969〜1974 年度括よび 1975〜 1978年度のグループに分けて比較整理したものであるが，高粘度 領域を除けば比較的良い一致と言光る。各研究所の測定值のうち CIC からの偏差が $\pm 0.20 \%$ 未満の割合を見ると，計量研究所の 84\% (3・2参照) 飞刘し，NBS，NPL，PTB がそれぞれ 72, 94, 94\%を占めている. これは各研究所の動粘度測定技術の優秀性を 示すものと考えられる. 


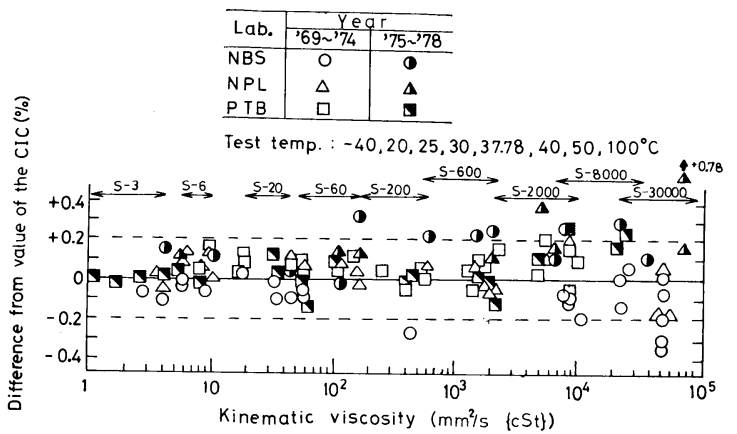

Fig. 4 Comparison of the results of the viscosity measurements performed at the NBS (U.S.A.), the NPL (England), and the PTB (West Germany) with those at the CIC.

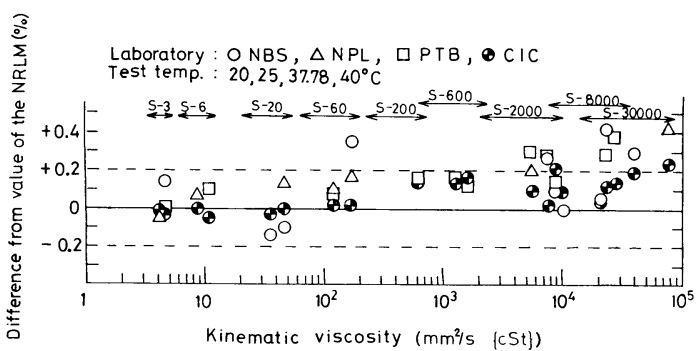

Fig. 5 Comparison of the results of the viscosity measurements performed at the NBS, the NPL, and the PTB with those at the NRLM.

な技，最近 4 年間の測定結果を見ると，NBS，NPL，PTB と も高粘度領域に怙ける測定值が CIC より高めで，その偏差は十 $0.10 〜+0.78 \%$, Fig. 2飞示した計量研究所とは逆の傾向を示 している.

\section{4-3 NBS, NPL, PTB と計量研究所の測定結果の比較}

$3 ・ 2$ で述べたように計量研究所では, Fig. 2 に示した標準液 そついてそれぞれの動粘度を測定したが，これと同一ロットの標 準液の動粘度を測定した研究所の中から NBS, NPL, PTB およ び CIC を選び, これらの測定結果と計量研究所の測定結果との 比較を試みた。 Fig. 5 はその結果を示したもので, 縦軸に計量研 究所の測定值からの偏差を, 横軸に標準液の動粘度をとって研究
所別にプロットしてある.

Fig. 5 から計量研究所との偏差は， $-0.15 \sim+0.42 \%$ 範囲内 にあることがわかる．S-3 から S-600の低粘度領域では， $17 の$ 測定值の $94 \%$ が計量研究所からの偏差で $\pm 0.20 \%$ 未満に入って打 り, 非常に良く一致している. S-2000 から S-30000 の高粘度領 域では13の測定值のうち, 計量研究所からの偏差で $\pm 0.20 \%$ 未満 に入っている割合は $31 \% ， \pm 0.30 \%$ 未満に入っている割合は $62 \%$ で, 低粘度領域に比べて偏差がやや大きくなってきて扣り, その 值は+0.00〜+0.42\%の範囲内であった.

\section{4・4 ASTM 高粘度標準液の粘度の安定性}

粘度標準液に要求される重要な性質の一つとして, 粘度の経時 変化が小さいことが挙げられる．現在用いられている標準液の組 成の物理的扣よび化学的性質は不変のものではなく, 長期間保存 したときには変質等による粘度の経時変化が，わずかではあるが 認められている.

容量 $500 \mathrm{ml}$ のガラスびんに試料を入れ密栓し，熱沶よび光を 避けた室温下で 1 年間保存したとき，S-3から S-600の低粘度標 準液では0.10\%以内の粘度增加が， S-2000 から S-30000 の高粘 度標準液では $0.10 〜 0.20 \%$ 程度の粘度増加が認められている11. また，S-2000 から S-30000 の高粘度標準液と同じ組成を持つ試 料で，日本工業規格 JISZ 88096) に規定された JS20H，JS60H お。 よび JS200H の高粘度標準液についても同様な条件下で保存した 場合は同程度の安定性を示すが，一度開栓して使用したのちびん 中に残った試料は, 残量によってその粘度变化の程度が異なり, 残量が少ないとき比較的大きい粘度増加（大きい例として, 残量 が $100 \mathrm{ml}$ のとき 1 年間の增加は $2 \%$ 程度) のあることが，筆者ら の測定により認められている77,8)。 このよ5に高粘度標準液は比 較的経時変化は大きいが，短期間での粘度測定では $3 \cdot 2,4 \cdot 1$, 4 ・2，4・3で述べてきたよ5な研究所間の偏差が $\pm 0.30 \%$ 以上に なる原因とは考觉がたい。

最近の CIC からの 私信 ${ }^{9)} に は ， S-2000$ から S-30000 の高粘 度標潐液の測定に括いて, 粘度計内に試料を採取してから長時間 経過後粘度測定を行うと大きな粘度增加があることが指摘されて いる. すなわち， $37.78^{\circ} \mathrm{C}$ 亿扣いてキャノンマスター拈よびキャ ノンウベローデマスター粘度計により， S-2000から S-30000の 動粘度を繰り返し測定した際, 測定のつど徐々に動粘度が増加す

Table VI Variation of the kinematic viscosity of oil samples S-2000, S-8000, and S-30000 with time elapsed in the respective viscometers. $\left.{ }^{9}\right)$

\begin{tabular}{|c|c|c|c|c|c|c|}
\hline \multirow{2}{*}{$\begin{array}{l}\text { Time elapsed after the } \\
\text { sample put } \\
\text { in the viscometer (hours) }\end{array}$} & \multicolumn{6}{|c|}{ Kinematic viscosity at $37.78^{\circ} \mathrm{C}\left(\mathrm{mm}^{2} / \mathrm{s}\{\mathrm{cSt}\}\right)$} \\
\hline & $\mathrm{CM}$ & CUM & $\mathrm{CM}$ & CUM & $\mathrm{CM}$ & CUM \\
\hline 2 & 1886.5 & 1887.6 & 7782.7 & 7783.3 & 26925 & 26916 \\
\hline 22 & $\begin{array}{l}1887.0 \\
(+0.03)\end{array}$ & $\begin{array}{l}1889.0 \\
(+0.07)\end{array}$ & $\begin{array}{l}7803.6 \\
(+0.27)\end{array}$ & $\begin{array}{l}7802.5 \\
(+0.25)\end{array}$ & $\begin{array}{l}27014 \\
(+0.33)\end{array}$ & $\begin{array}{l}27031 \\
(+0.43)\end{array}$ \\
\hline 30.2 & $\begin{array}{l}1890.1 \\
(+0.19)\end{array}$ & $\begin{array}{l}1890.9 \\
(+0.17)\end{array}$ & $\begin{array}{l}7811.7 \\
(+0.37)\end{array}$ & $\begin{array}{l}7813.3 \\
(+0.39)\end{array}$ & $\begin{array}{l}27052 \\
(+0.47)\end{array}$ & $\begin{array}{l}27066 \\
(+0.56)\end{array}$ \\
\hline 44.8 & $\begin{array}{l}1890.1 \\
(+0.19)\end{array}$ & $\begin{array}{l}1891.8 \\
(+0.22)\end{array}$ & $\begin{array}{l}7821.3 \\
(+0.50)\end{array}$ & $\begin{array}{l}7824.2 \\
(+0.53)\end{array}$ & $\begin{array}{l}27070 \\
(+0.54)\end{array}$ & $\begin{array}{l}27081 \\
(+0.61)\end{array}$ \\
\hline 143 & $\begin{array}{l}1894.5 \\
(+0.42)\end{array}$ & $\begin{array}{l}1892.7 \\
(+0.27)\end{array}$ & $\begin{array}{l}7835.0 \\
(+0.67)\end{array}$ & $\begin{array}{l}7819.2 \\
(+0.46)\end{array}$ & $\begin{array}{l}27115 \\
(+0.71)\end{array}$ & $\begin{array}{l}27181 \\
(+0.98)\end{array}$ \\
\hline
\end{tabular}

Note: CM: Cannon Master Viscometer, CUM: Cannon-Ubbelohde Master Viscometer The figures in parenthes indicate the increment of kinematic viscosity from the value determined at 2 hours after sample put in the viscometer in percent. 
る傾向が観測されたという，Table VI はその測定結果であるが， 粘度計内に標準液を採取してからの経過時間によって動粘度測定 值は增加している.したがって, 高粘度標準液を受け持った研究 所が粘度計内に標準液を採取後, ぞれ位の時間で動粘度測定を終 了したかによって, 研究所間の測定值に違いが生じる可能性があ る.

計量研究所では 6 〜 時間で測定を終了しているが，NPL で は測定の前日に標準液を粘度計内に採取していることが報告され

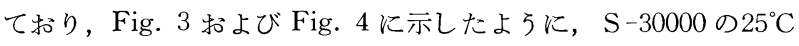
における NPL の測定值は, CIC からの偏差が $+0.78 \%$ と大さ 值をとっている原因と考光られる. 計量研究所の動粘度測定值が 高粘度領域において, 他の研究所より低めの傾向であることの原 因と併せて今後検討を要する課題である.

\section{5. おわりに}

1969 1978年度の10年間にわたって計量研究所が参加してきた ASTM 粘度標準液の粘度の国際比較についてその概要, 筆者ら によって行われた計量研究所での測定およびその結果, 並びに参 加研究所間の比較を述べたが，これを要約すると次のようになる.

（1）1978年度までの10年間における計量研究所の測定結果は， この国際比較の幹事役であるCICの測定結果と比較すると, S-3 から S-600の低粘度領域では全測定值が $00.20 \%$ 未満の偏差に入 って扣り，非常に良く一致しているＳ－2000から S-30000の高 粘度領域では全測定值の $72 \%$ $\pm 0.20 \%$ 未満の偏差に入っている ことがわかった. 特に1975〜1977年度の測定においてー0.30\%以 上の偏差を示した S-8000 の標準液については，1978年度の測定 の際, 落球粘度計により粘度の絶対測定を行い, 標準粘度計の測 定值との比較を行ってみた. その結果, 両者の值の差は $0.10 \%$ で 一致し， $-0.30 \%$ 以上の偏差を生じるような系統鿁差は, 筆者ら が行った粘度測定では考えられないことを確かめた。

（2）1978年度に㧊ける9 力国22研究所の測定結累は，CICとの 比較に扔いて, 全測定值の $76 \%$ $\pm 0.20 \%$ 未満の偏差に入ってい ることがわかった. また, 計量研究所と CIC の比較では, 高粘 度標準液を含めた全測定值が， $\pm 0.20 \%$ 未満の偏差に入っている ことがわかった。

(3) NBS, NPL，PTB 等の著名な国立計量標準研究所の測定 結果は, CIC との比較に执いて， $\pm 0.20 \%$ 未満の偏差に入ってい
る割合をみると，NBS，NPL 拉よび PTB がそれぞれ72\%，94 \%拈よび94\%を占めていることがわかった。 しかし，高粘度領域 では各研究所とも CIC の測定值上り高めで，その偏差は+0.10 〜 $+0.78 \%$, 計量研究所の結果とは逆の傾向を示していること がわかった。

（4）計量研究所と同じ種類の標隻液の動粘度を測定した NBS, NPL, PTB の測定結果は, 計量研究所との比較に扣いて, 低粘

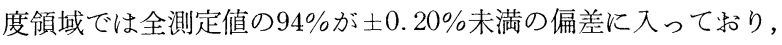
非常に良く一致している. しかし, 高粘度領域では計量研究所の 測定值より高めで，その偏差は+0.00〜+0.42\%であることがわ かった.

(5) 国立の研究所ばかりでなく, 粘度測定を必要としている公 立拉よび民間の研究所が数多く参加していることから，国際間の 粘度測定の現状を知ることができたが，これらの研究所でも高粘 度領域での偏差が大きくなっており, これは 4 ・4 で述べた高粘 度標準液の粘度の安定性とも関連して今後の検討課題の一つと考 えられる。

（昭和53年10月24日第26回レオロジ一討論会にて講演）

\section{参 考 文 献}

1) Report of the Annual ASTM Cooperative Viscosity Testing Program (1969 1978).

2）計量研究所邦訳, “解説 1968年国際実用温度目盛”, p. 1 (1971) コロナ社.

3) Kawata, M., K. Kurase, and K. Yoshida, Bulletin of the NRLM, No. 20, 16 (1970).

4）倉野恭充, 吉田清, 倉瀬公男, 計量研究所報告, 25, No. 2,29 (1976).

5）吉田清, 川田裕郎, 倉瀬公男, 計量研究所報告, 15, No. 1,24 (1966).

6）JISZ 8809-1978, 粘度計校正用標準液.

7）吉田清, 倉瀬公男, 倉野恭充, 小野山益弘, 材料, 22, No. 236, 114 (1973).

8）倉野恭充，倉瀬公男，計量研究所報告， 27, No. 2, 37 (1978).

9) CIC Dr. Manning からの川田宛の私信 (1978). 